\title{
Qualitative feed restriction on productive performance and lipid metabolism in broiler chickens
}

[Restrição alimentar qualitativa sobre o desempenho produtivo e o metabolismo lipídico em frango de corte]

\author{
S. Cornejo ${ }^{1}$, A.C. Gadelha ${ }^{2}$, J. Pokniak ${ }^{1 *}$, G. Villouta ${ }^{1}$ \\ ${ }^{1}$ Facultad de Ciencias Veterinarias y Pecuarias - Universidad de Chile \\ Avda. Santa Rosa, 11735 \\ Santiago, Chile \\ ${ }^{2}$ Departamento de Zootecnia - UFC - Fortaleza, CE
}

\begin{abstract}
A trial was carried out to evaluate the effect of qualitative restriction at different rearing phases on liver fatness and plasma triglycerides without impairing the productive performance of broiler chickens. One hundred and seventy-six male chicks were randomly assigned to four treatments and reared in battery brooders (16 pens with 11 birds each) from 1 to 49-day-old. In the control group, chicks were fed a starter diet (1 to 28 -day-old) with $3,300 \mathrm{kcal} \mathrm{ME} / \mathrm{kg}$ of diet and $22.5 \% \mathrm{CP}$; grower diet (29 to 42-day-old) $3,300 \mathrm{kcal} \mathrm{ME} / \mathrm{kg}$ of diet and $18.2 \% \mathrm{CP}$; and the finisher diet (43 to 49-day-old) 3,300kcal ME/kg and $18.2 \% \mathrm{CP}$. Three restrict groups were fed a low $2,800 \mathrm{kcal} \mathrm{ME} / \mathrm{kg}$ of diet and $24 \% \mathrm{CP}$ from 7 to 14 -dayold (treatment 1); from 7 to 21-day-old (treatment 2); and from 22 to 35-day-old (treatment 3). All treatments were fed control diet before and after the feed restriction period. Feed intake was not affected during the feed restriction period; nevertheless, weight gain was lower $(\mathrm{P}<0.05)$ for chicks fed restricted diet from 7 to 21 and from 21 to 35-day-old. At the end of each restriction period, scores of liver for fatty infiltration were higher in restricted birds compared to control birds, although no changes were detected in plasma triglyceride levels. On the $49^{\text {th }}$ day of age, less intracellular fatty infiltration was observed in the liver of previously restricted birds compared to control birds, and weight gain was also lower in the restricted groups. Moreover, triglyceride plasma levels were similar among treatments, but decreased in 12-hour-fasted broilers compared to non-fasted birds. The low energy:protein ratio diet affected weight gain and fatty infiltration in the liver, but had no effect on plasma levels of triglycerides.
\end{abstract}

Keywords: broiler chicken, feed restriction, productive performance, liver, triglyceride

\section{RESUMO}

Aplicou-se restrição alimentar qualitativa em frangos de corte, em diferentes fases do crescimento, para reduzir a infiltração gordurosa do fígado e os triglicerídeos plasmáticos, sem influir nas respostas produtivas. Distribuíram-se aleatoriamente 176 pintos machos em quatro tratamentos. As aves foram alojados em baterias (16 gaiolas com 11 aves cada) e foram criados de 1 a 49 dias de idade. No grupo controle as aves foram alimentadas com dieta inicial (1-28 dias) com 3.300kcal EM/kg/dieta e 22,5\% de proteína bruta (PB; dieta de crescimento (29-42 dias) com 3.300kcal EM/kg/dieta e 20,9\% de PB; dieta de acabamento (43-49 dias de idade) $3.300 \mathrm{kcal} \mathrm{EM/kg} /$ dieta e 18,2\% de PB. As aves nos três grupos sob restrição foram alimentadas com dieta com $2.800 \mathrm{kcal}$ de EM/kg/dieta e 24\% de PB de 7 aos 14 dias de idade (tratamento 2), de 7 aos 21 dias de idade (tratamento 2) e de 22 aos 35 dias de idade (tratamento 3). Todas as aves dos tratamentos sob restrição foram alimentadas com a dieta controle antes e depois do periodo de restrição alimentar. Ao final de cada periodo de restrição foi observada uma maior infiltração gordurosa no figado (representado pela composição química e escore histológico). Também não houve diferenças entre os triglicerideos plasmáticos, quando comparado com o controle. Aos 49 dias

Recebido em 10 de agosto de 2005

Aceito em 30 de novembro de 2007

*Corresponding author (autor para correspondência)

E-mail:.jpokniak@uchile.cl 
Qualitative feed restriction on productive...

de idade, o ganho de peso total e a infiltração gordurosa no figado, foram menores nos grupos restritos. Os níveis de triglicérides plasmáticos, entretanto, foram semelhantes entre os tratamentos, mas reduziram nas aves com aplicação de jejum de 12 horas, quando comparados com aves sem jejum. A baixa relação energia/proteina da dieta afetou o ganho de peso e a infiltração gordurosa no figado, mas não alterou os valores de triglicérides plasmáticos.

\section{Palavras-chave: frango de corte, restrição alimentar, resposta produtiva, figado, triglicéride}

\section{INTRODUCTION}

The incidence of heart diseases have increased in humans in the past years and has been associated to high fat consumption, especially saturated fat. Consequently, the consumption of meat containing lower levels of saturated fat (white meat), such as poultry, has increased. Qualitative and/or quantitative feed restriction of broilers might reduce the amount of fat or abdominal fat in carcasses. Qualitative restriction is related to nutrient dilution in the diet, whereas quantitative restriction to limiting the amount of feed daily given to the animals (Pokniak and Cornejo, 1982; Leeson and Zubair 1997).

Qualitative feed restriction is performed using diets with low energy to protein ratio (EPR); this is accomplished when dietary protein is increased or dietary energy is decreased or kept constant. As a consequence, the relative excess of protein induces higher energy utilization and, therefore, more synthesis and excretion of uric acid (Bartov, 1979). Unsaturated fatty acids (Clarke et al., 1990) or some drugs, such as beta agonists (Dalrymple et al., 1984), have been evaluated as a means to reduce fat levels in carcass, but the results are inconsistent. Quantitative restriction has been used for different purposes, such as reduction of broiler mortality and reduction of long bone abnormalities (Gonzales et al., 1998; Pelicano et al., 2005). Carcass fatness has decreased without impairment of body weight gain in broilers, but conflicting results have also been reported (Cornejo, et al., 1991; Furlan et al., 2002). Mathematic models have shown that the maximum abdominal fat weight is observed in 43-day-old broilers, whereas maximum abdominal fat gain expressed as carcass and live weight percentages occurs on the $15^{\text {th }}$ and $19^{\text {th }}$ day of age, respectively (Tzeng and Becker, 1981).

In poultry, the major site of "de novo" fat synthesis is the liver (Saadoun and Leclerq,
1987). Griffin et al. (1992) observed that the accumulated fat originated from plasma triglycerides, which in turn derived from the diet or were synthesized in the liver. Plasma triglycerides are detected as very low or lowdensity lipoprotein (VLDL and LDL, Griffin et al., 1982). According to Griffin and Whitehead (1982), VLDL-derived triglycerides are more available for fatty acid synthesis. In broilers, the levels of VLDL and LDL are correlated to fat deposition in the carcass. A twelve-hour fasting has been reported to reduce triglyceride plasma levels (Nir et al., 1984), and less liver lipogenesis has been observed in broilers that were fed diets containing higher proportions of energy derived from protein (Tanaka et al., 1983a). Based on these previous observations, an experiment was carried out to evaluate the effect of qualitative feed restriction on the performance, liver histology, and some variables of lipid metabolism in male broiler chickens.

\section{MATERIAL AND METHODS}

One hundred and seventy-six Hubbard broiler chicks were randomly assigned to four treatments in four replicates with 11 chicks each. The birds were reared from 1 to 28-day-age in battery brooders in an environmentally controlled room. On the $29^{\text {th }}$ day of age, birds were transferred to batteries and reared until 49day-old. During the first week, temperature was set at $33^{\circ} \mathrm{C}$, and then it was decreased $3^{\circ} \mathrm{C}$ per week until $24^{\circ} \mathrm{C}$. A 10 -hours/day artificial light program was used during all the experiment. Water and feed were given ad libitum. The control group was fed a starter diet (1 to 28-dayold) with $3,300 \mathrm{kcal} \mathrm{ME} / \mathrm{kg} ; 22.5 \% \mathrm{CP}$, and energy to protein ratio (EPR) of 146.7. The grower diet (29 to 42 days-old) had 3,300kcal $\mathrm{ME} / \mathrm{kg} ; 20.9 \% \mathrm{CP}$ and EPR of 157.9 , and the levels in the finisher diet (43 to 49-day-old) were $3,300 \mathrm{kcal} \mathrm{ME} / \mathrm{kg} ; 18.2 \% \mathrm{CP}$ and EPR of 181.3 . Three restricted groups $(\mathrm{R})$ were fed a low EPR diet having 2,800kcal $\mathrm{ME} / \mathrm{kg}$ and $24 \% \mathrm{CP}$ $(\mathrm{EPR}=117)$ from 7 to 14-day-old (R-1), 7 to 21 - 
day-old (R-2), or 21 to 35-day-old (R-3). All treatments were fed the control diet before and after the periods of feed restriction (Table 1).

Body weight gain, feed intake and feed conversion were weekly recorded. On the $14^{\text {th }}$, $21^{\text {st }}, 35^{\text {th }}$ and $49^{\text {th }}$ day of age, liver samples were collected from one broiler per replicate. Histological sections were prepared, stained with Sudan III, and scored for liver fatty infiltration according to Lopez et al. (1982).

Table 1. Composition and chemical analysis of the experimental diets for broiler chickens

\begin{tabular}{|c|c|c|c|c|}
\hline \multirow{2}{*}{ Ingredient (kg/ton) } & \multicolumn{4}{|c|}{ Diet } \\
\hline & Starter & Grower & Finisher & Restricted \\
\hline Yellow Corn & 599.93 & 719.74 & 787.81 & 586.04 \\
\hline Corn oil & 65.77 & 45.17 & 34.34 & - \\
\hline Soybean meal & 177.86 & 86.65 & 37.66 & 155.57 \\
\hline Fish meal & 140.00 & 130.00 & 120.00 & 99.82 \\
\hline Wheat middlings & - & - & - & 39.13 \\
\hline Sunflower meal & - & - & - & 100.00 \\
\hline Sodium chloride & 1.50 & 1.50 & 1.50 & 1.50 \\
\hline Oyster meal & 11.94 & 12.25 & 11.91 & 11.58 \\
\hline Tricalcium phosphate & - & 1.69 & 3.77 & 3.37 \\
\hline Supplement ${ }^{1}$ & 3.00 & 3.00 & 3.00 & 3.00 \\
\hline \multicolumn{5}{|l|}{ Calculated analysis $(\%)^{2}$} \\
\hline $\mathrm{ME}(\mathrm{kcal} / \mathrm{kg})$ & 3,300 & 3,300 & 3,300 & 2,800 \\
\hline Lysine & 1.45 & 1.17 & 1.00 & 1.32 \\
\hline Methionine and cysteine & 0.92 & 0.83 & 0.76 & 0.90 \\
\hline Tryptophan & 0.29 & 0.23 & 0.20 & 0.30 \\
\hline Linoleic acid & 4.81 & 3.86 & 3.37 & 1.34 \\
\hline Energy:protein ratio & 146.7 & 157.9 & 181.3 & 116.2 \\
\hline \multicolumn{5}{|l|}{ Chemical analysis $(\%)^{3}$} \\
\hline Dry matter & 90.3 & 87.5 & 89.3 & 90.0 \\
\hline Crude fiber & 2.2 & 1.9 & 1.8 & 3.9 \\
\hline Ether extract & 9.1 & 7.8 & 7.4 & 4.3 \\
\hline Nitrogen free extract & 51.9 & 52.4 & 55.9 & 52.9 \\
\hline Ash & 4.6 & 4.5 & 6.0 & 4.8 \\
\hline Crude protein & 22.5 & 20.9 & 18.2 & 24.1 \\
\hline
\end{tabular}

${ }^{\mathrm{T}}$ Provided per kg of diet: vit.A, 5,000IU; vit.D3, 2,000IU; vit.E, 11IU; vit.K, 0.75mg; vit.B1, 1.5mg; vit.B2, 4.5mg; d-pantothenic acid (100\%), 12mg; niacin, 30mg; vit.B6, 2.5mg; choline chloride (50\%), 110mg; folic acid, 1mg; biotin (2\%), 4mg; vit.B12 (0.1\%), $9 \mu \mathrm{g}$; ethoxyquin (antioxidant), 125mg; olaquindox (100\%), 20mg; Cu, $3.5 \mathrm{mg}$; I, $0.17 \mathrm{mg}$; Fe, 25mg; Zn, 30mg; Mn, 66mg; Se, 0.1mg; Co, 0.1mg. Composition informed by Feed Champion SA, Chile.

${ }^{2}$ Calculated values as suggested by González and Pokniak (1990).

${ }^{3}$ According to Methods... (1995).

Fatty infiltration was scored as light $=(+: 1)$; little $=(++: 2)$; mild $=(+++: 3)$; and high $=$ $(++++$ : 4). Mean treatment scores were calculated as the sum of the products between the number of broilers and the respective scores. Thus, mean scores ranged from 4 (four broilers with score 1) to 16 (four broilers with score 4). On the $49^{\text {th }}$ day of age, the chemical composition 
of the liver was evaluated following the AOAC procedures (Methods..., 1995).

Triglyceride (TGL) analysis was performed in blood samples collected from two broilers per replicate on the $14^{\text {th }}, 21^{\text {st }}, 28^{\text {th }}, 35^{\text {th }}, 42^{\text {nd }}$ and $49^{\text {th }}$ day of age. The birds had been fasted or not for 12 hours previously to blood sampling. The GPO-PAP enzyme methods ${ }^{1}$ were used to measure TGL of the VLDL plus LDL fractions, as suggested by Segovia et al. (1990).

Data were submitted to analysis of variance (Model I) and mean differences were analyzed by Duncan's test (Sokal and Rohlf, 1981). Histology scores were evaluated using a nonparametric test (Fisher's exact test or Kruskal Wallis test).

Table 2. Performance of broilers fed control diet or submitted to qualitative restriction in different periods $($ mean $\pm \mathrm{SD})$

\begin{tabular}{|c|c|c|c|c|c|}
\hline \multirow{2}{*}{$\begin{array}{l}\text { Weeks } \\
\text { of age }\end{array}$} & \multicolumn{4}{|c|}{ Treatment } & \multirow[b]{2}{*}{$\mathrm{P}$ value* } \\
\hline & Control $(\mathrm{C})$ & $7-14 d^{1}(R-1)$ & $7-21 d^{1}(R-2)$ & $21-35 d^{1}(R-3)$ & \\
\hline \multicolumn{6}{|c|}{ Weekly weight gain (g) } \\
\hline 1 & $104 \pm 14.1$ & $99 \pm 17.2$ & $100 \pm 16.6$ & $101 \pm 14.5$ & NS \\
\hline 2 & $226 \pm 33.8$ & $218 \pm 20.3$ & $212 \pm 31.2$ & $226 \pm 29.3$ & \\
\hline 3 & $353 \pm 33.6 a$ & $338 \pm 43.6 \mathrm{a}$ & $313 \pm 38.5 b$ & $347 \pm 37.2 \mathrm{a}$ & 0.001 \\
\hline 4 & $440 \pm 4.6 \mathrm{a}$ & $439 \pm 61.3 \mathrm{a}$ & $400 \pm 47.4 b$ & $348 \pm 59.9 c$ & 0.001 \\
\hline 5 & $458 \pm 57.0 \mathrm{a}$ & $446 \pm 59.4 \mathrm{ab}$ & $416 \pm 79.2 b c$ & $400 \pm 67.1 \mathrm{c}$ & 0.001 \\
\hline 6 & $535 \pm 62.0 \mathrm{ab}$ & $499 \pm 89.1 \mathrm{bc}$ & $490 \pm 88.0 \mathrm{c}$ & $544 \pm 65.1 \mathrm{a}$ & 0.019 \\
\hline 7 & $527 \pm 67.4$ & $472 \pm 113.3$ & $461 \pm 109.6$ & $496 \pm 130.7$ & NS \\
\hline Total & $2653 \pm 205 a$ & $2521260 b$ & $2395 \pm 275 b$ & $2477 \pm 241 b$ & 0.001 \\
\hline \multicolumn{6}{|c|}{ Weekly feed intake (g) } \\
\hline 1 & $106 \pm 6.1$ & $102 \pm 7.9$ & $103 \pm 4.7$ & $101 \pm 5.2$ & NS \\
\hline 2 & $289 \pm 6.5$ & $308 \pm 7.2$ & $302 \pm 19.2$ & $293 \pm 3.2$ & NS \\
\hline 3 & $496 \pm 13.4$ & $499 \pm 7.0$ & $520 \pm 30.0$ & $497 \pm 4.1$ & NS \\
\hline 4 & $747 \pm 17.1$ & $742 \pm 54.4$ & $709 \pm 46.0$ & $713 \pm 23.3$ & NS \\
\hline 5 & $934 \pm 27.7$ & $904 \pm 71.1$ & $855 \pm 29.3$ & $937 \pm 73.5$ & NS \\
\hline 6 & $1196 \pm 17.0 \mathrm{a}$ & $1109 \pm 62.2 b c$ & $1075 \pm 53.0 \mathrm{c}$ & $1185 \pm 62.4 \mathrm{ab}$ & 0.019 \\
\hline 7 & $1282 \pm 43.3 \mathrm{a}$ & $1147 \pm 96.9 b$ & $1121 \pm 104.0 \mathrm{~b}$ & $1200 \pm 32.2 \mathrm{ab}$ & 0.051 \\
\hline Total & $5049 \pm 60.5 \mathrm{a}$ & $4813 \pm 249 \mathrm{ab}$ & $4686 \pm 153.3 b$ & $4922 \pm 134.0 \mathrm{ab}$ & 0.047 \\
\hline \multicolumn{6}{|c|}{ Weekly feed conversion } \\
\hline 1 & $1.02 \pm 0.03$ & $1.03 \pm 0.01$ & $1.02 \pm 0.01$ & $1.00 \pm 0.05$ & NS \\
\hline 2 & $1.28 \pm 0.05 \mathrm{a}$ & $1.42 \pm 0.02 b$ & $1.42 \pm 0.06 \mathrm{~b}$ & $1.30 \pm 0.02 \mathrm{a}$ & 0.001 \\
\hline 3 & $1.41 \pm 0.05 \mathrm{a}$ & $1.48 \pm 0.05 \mathrm{a}$ & $1.67 \pm 0.05 b$ & $1.44 \pm 0.09 \mathrm{a}$ & 0.001 \\
\hline 4 & $1.70 \pm 0.07 \mathrm{a}$ & $1.69 \pm 0.05 \mathrm{a}$ & $1.78 \pm 0.08 \mathrm{a}$ & $2.06 \pm 0.12 b$ & 0.001 \\
\hline 5 & $2.04 \pm 0.07 \mathrm{a}$ & $2.02 \pm 0.021 \mathrm{a}$ & $2.06 \pm 0.11 \mathrm{a}$ & $2.38 \pm 0.26 \mathrm{~b}$ & 0.015 \\
\hline 6 & $2.23 \pm 0.05$ & $2.21 \pm 0.11$ & $2.20 \pm 0.20$ & $2.18 \pm 0.10$ & NS \\
\hline 7 & $2.43 \pm 0.04$ & $2.46 \pm 0.27$ & $2.45 \pm 0.10$ & $2.43 \pm 0.10$ & NS \\
\hline Total & $1.90 \pm 0.01 \mathrm{a}$ & $1.91 \pm 0.05 a$ & $1.96 \pm 0.03 \mathrm{ab}$ & $2.00 \pm 0.06 \mathrm{~b}$ & 0.032 \\
\hline
\end{tabular}

${ }^{1}$ Period in which qualitative restriction diet was given [Energy to protein ratio $(\mathrm{EPR}=117)$ ].

* Means followed by different letters in the same row are different $(\mathrm{P}<0.05)$. NS $=$ non significant.

\footnotetext{
${ }^{1}$ Merck test, Merck - Darmstest, Germany
} 
Qualitative restriction for $15 \mathrm{~d}$ had different negative impacts on WWG according to the age of birds; impairment was greater due to restriction between 7 and 21-day-old animals (R2 ). On the other hand, early restriction for one week (R-1) had no negative effects on weight gain.

Weekly feed intake (WFI) was not affected during the restriction periods $(\mathrm{P}>0.05)$. Conversely, feed intake was lower in R-1 and R2 in comparison to the control group on $6^{\text {th }}$ and $7^{\text {th }}$ week of age $(\mathrm{P}<0.019$ and $\mathrm{P}<0.051$, respectively for $6^{\text {th }}$ and $7^{\text {th }}$ week of age). Total feed intake (1 to 49-day-old) in R-2 was lower than in the control group $(\mathrm{P}<0.047)$, but similar to the other restricted groups.

Weekly feed conversion (WFC) reflected weight gain and feed intake results, suggesting that feed conversion was impaired during the restriction period $(\mathrm{P}<0.001)$. However, this effect was not observed on the $6^{\text {th }}$ and $7^{\text {th }}$ week of age. Total feed conversion was better in the control group and poorer in $\mathrm{R}-3 \quad(\mathrm{P}<0.032)$. There were no statistical differences at this age between the other treatments. Apparently, the evaluation period was not long enough for R-3 birds recover, and it is possible that rearing periods longer than 49 days would enable recovery in this group.

Liver histology was normal (Table 3), although intracellular fatty infiltration was observed. The liver showed visible and clean parenchyma, evident lobules, septum and sinusoids, besides clean and thin endothelial membranes (Fig. 1, 2, and 3). Hepatocytes were clear, with typical pyramidal structure, and normal polyploidy in some areas. The cells were normally involved by a microfibrillar net of reticular tissue. All features confirm a normal hepatic structure and suggest healthy functionality, in spite of the different fatty infiltration degrees that were observed.

Table 3. Scores of liver fatty infiltration (Sudan III stain) at the end of each qualitative restriction period and on the $49^{\text {th }}$ day of age

\begin{tabular}{lcccc}
\hline \multirow{2}{*}{ Treatment } & \multicolumn{3}{c}{ Score $^{1}$} \\
\cline { 2 - 5 } & $14 \mathrm{~d}$ & $21 \mathrm{~d}$ & $35 \mathrm{~d}$ & $49 \mathrm{~d}$ \\
\hline Control ( C $)$ & $5(3 \times 1+1 \times 2)^{1}$ & $4(4 \times 1)$ & $5(3 \times 1+1 \times 2)$ & $14(2 \times 3+2 \times 4) \mathrm{a}$ \\
$7-14 \mathrm{~d}(\mathrm{R}-1)$ & $7(3 \times 1+1 \times 4)$ & & & $9(1 \times 1+1 \times 2+2 \times 3) \mathrm{ab}$ \\
$7-21 \mathrm{~d}(\mathrm{R}-2)$ & & $8(4 \times 2)$ & & $8(1 \times 1+2 \times 2+1 \times 3) \mathrm{ab}$ \\
$21-35 \mathrm{~d}(\mathrm{R}-3)$ & & & $12(4 \times 3)$ & $6(2 \times 1+2 \times 2) \mathrm{ab}$ \\
$\mathrm{P} \leq *$ & $1.00^{2}$ & $0.029^{2}$ & $0.029^{2}$ & $0.018^{3}$
\end{tabular}

"Means followed by different letters in the same columns are different $(\mathrm{P}<0.05)$

${ }^{1}$ Score means (sum of the products between the number of affected birds and score: see Material and Methods).

${ }^{2}$ Fisher's Exact Test.

${ }^{3}$ Kruskal Wallis Test.

At the end of the different restriction periods (Table 3), higher degrees of fatty infiltration were observed in the hepatocytes of restricted birds in relation to control birds. According to histology scores, intracellular fat was $40 \%$, higher for R-1, 100\% for R-2 and 140\% for R-3 compared to control birds. However, this tendency was reverted on the $49^{\text {th }}$ day of age. Intracellular fatty infiltration scores decreased to
$35.7 \%, 42.9 \%$, and $57.1 \%$ for R-1, R-2, and R-3, respectively.

Proximate analysis of the liver samples collected on the $49^{\text {th }}$ day of age (Table 4) is in accordance with the scores of intracellular fatty infiltration shown in Table 3. 


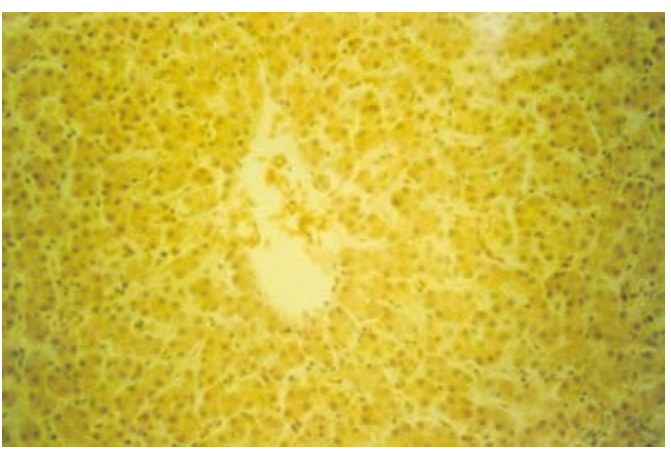

Figure 1. Photomicrograph of broiler chicken liver tissue stained with Sudan III showing light $(+)$ fatty infiltration (100x magnification).

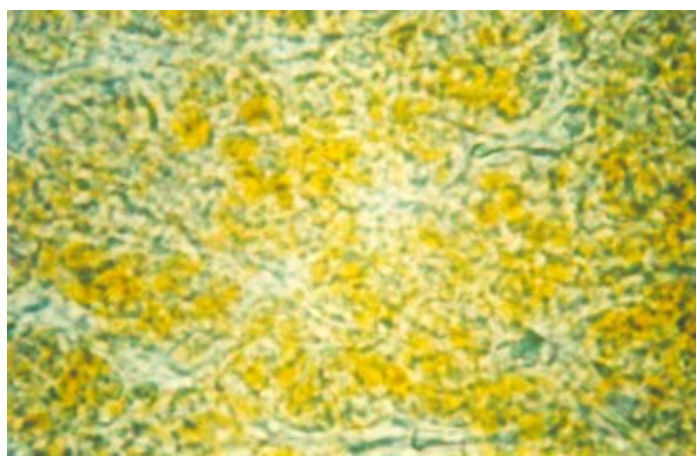

Figure 3. Photomicrograph of broiler chicken liver tissue stained with Sudan III showing mild $(+++)$ fatty infiltration (100x magnification).

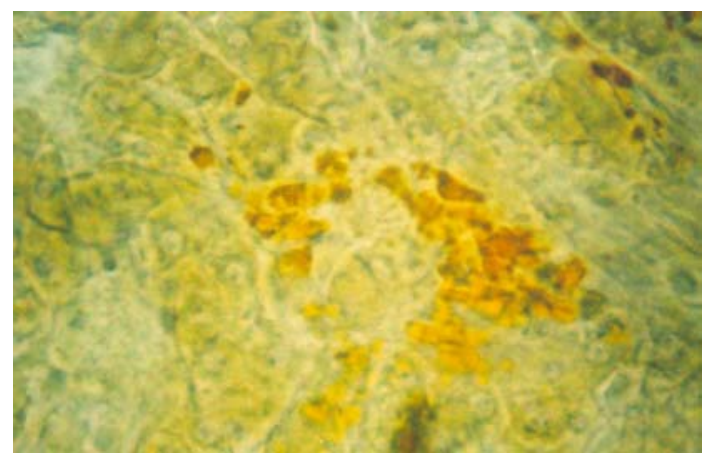

Figure 2. Photomicrograph of broiler chicken liver tissue stained with Sudan III showing little $(++)$ fatty infiltration (400x magnification).

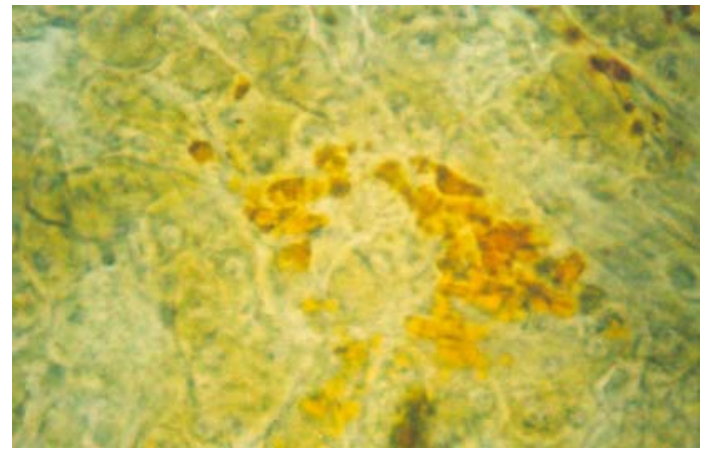

Figure 2. Photomicrograph of broiler chicken liver tissue stained with Sudan III showing little $(++)$ fatty infiltration (400x magnification).

Table 4. Proximate analysis of the liver (fresh matter basis, \%) at 49 days of age after different periods of qualitative restriction (mean \pm SE)

\begin{tabular}{lccc}
\hline Treatment & Dry matter $(\mathrm{DM})$ & Crude protein $(\mathrm{CP})$ & Ether extract $(\mathrm{EE})$ \\
\hline Control & $34.8 \pm 3.2$ & $19.4 \mathrm{~b} \pm 1.6$ & $10.3 \mathrm{a} \pm 3.0$ \\
7-14d (R-1) & $32.1 \pm 3.1$ & $20.6 \mathrm{ab} \pm 1.6$ & $6.6 \mathrm{~b} \pm 2.3$ \\
$7-21 \mathrm{~d}(\mathrm{R}-2)$ & $31.9 \pm 2.3$ & $22.9 \mathrm{a} \pm 2.00$ & $5.5 \mathrm{~b} \pm 2.0$ \\
$21-35 \mathrm{~d}(\mathrm{R}-3)$ & $29.7 \pm 1.3$ & $20.3 \mathrm{ab} \pm 1.4$ & $4.8 \mathrm{~b} \pm 1.3$ \\
$\mathrm{p} \leq *$ & $\mathrm{NS}$ & 0.056 & 0.020 \\
\hline
\end{tabular}

*Means followed by different letters in the same column are different $(\mathrm{P}<0.05)$.

Lower ether extract content $(\mathrm{P}<0.02)$ was observed in the liver of restricted birds at the end of the trial in comparison to control birds. Fat levels were also lower in the treatments with shorter periods to recover from restriction. Crude protein levels tended to increase in the restricted groups, and the difference between R-2 and control was almost significant $(\mathrm{P}>0.56)$.

Triglyceride levels were not different $(\mathrm{P}>0.05)$ between treatments (Table 5), except for nonfasted birds from R-2 compared to control birds
$(\mathrm{P}<0.05)$ on the $28^{\text {th }}$ day of age. As expected, broilers subjected to 12 hours of fasting showed triglyceride levels lower than non-fasted chicks. It is worth mentioning that the lower TGL values obtained in 21-day-old broilers were quite similar to those obtained for the fasted broilers.

\section{DISCUSSION}

Qualitative restriction decreased weight gain during the rearing period. Compensatory growth was not stimulated by such decrease, as observed 
by the lower total weight gain of restricted birds compared to control birds (1 to 49-day-old, Table 2). Conversely, Plavnik and Hurwitz (1991) reported compensatory growth in birds submitted to more stringent conditions of restriction. Body weight reduction was reported to be $26 \%$ and $36 \%$, i.e., greater than the values observed in the present study. Apparently, greater reductions in weight gain are needed to trigger the physiological mechanisms of compensatory growth (Boza et al., 1999). On the other hand, Zubair and Leeson (1996) subjected broilers to severe early feed restriction and did not observe compensatory growth on the $49^{\text {th }}$ day of age.

Table 5. Plasma triglycerides $(\mathrm{mg} / \mathrm{dl})$ in broilers subjected or not to fasting for 12 hours

\begin{tabular}{|c|c|c|c|c|c|c|}
\hline & \multicolumn{6}{|c|}{ Age $(d)$} \\
\hline & 14 & 21 & 28 & 35 & 42 & 49 \\
\hline \multicolumn{7}{|c|}{ Fasted } \\
\hline $\mathrm{C}$ & $20.0 \pm 3.2$ & $14.0 \pm 1.8$ & $28.3 \pm 2.5$ & $22.5 \pm 9.1$ & $11.3 \pm 2.1$ & $19.0 \pm 7.4$ \\
\hline R-1 & $18.0 \pm 3.5$ & $18.5 \pm 5.6$ & & & & $15.3 \pm 5.0$ \\
\hline $\mathrm{R}-2$ & & $20.3 \pm 8.3$ & $24.5 \pm 4.2$ & & & $14.0 \pm 5.0$ \\
\hline $\mathrm{R}-3$ & & & & $19.3 \pm 6.9$ & $14.3 \pm 4.0$ & $12.0 \pm 1.2$ \\
\hline \multicolumn{7}{|c|}{ Non-fasted } \\
\hline $\mathrm{C}$ & $100.3 \pm 25.6$ & $27.0 \pm 7.5$ & $128.0 \pm 20.2 \mathrm{a}$ & $63.5 \pm 14.7$ & $118.5 \pm 8.1$ & $66.8 \pm 32.4$ \\
\hline $\mathrm{R}-1$ & $73.8 \pm 24.5$ & $18.5 \pm 6.0$ & & & & $42.3 \pm 7.4$ \\
\hline $\mathrm{R}-2$ & & $21.8 \pm 2.2$ & $71.0 \pm 38.2 b$ & & & $73.5 \pm 28.8$ \\
\hline $\mathrm{R}-3$ & & & & $44.5 \pm 18.0$ & $90.5 \pm 31.0$ & $63.5 \pm 7.5$ \\
\hline
\end{tabular}

*Means followed by different letters in the same column are different $(\mathrm{P}<0.05)$.

Restricted broilers have not increased feed intake to compensate for the lower dietary energy levels. Therefore, energy and protein intake was lower in restricted birds compared to control birds and resulted in lower weight gain. These results corroborate the findings of Bartov and Plavnik (1998) who reported that intake in broilers is very close to the maximum capacity of the digestive tract. However, Leeson et al. (1992) observed an increase in feed intake during qualitative feed restriction in older broilers.

The lower feed intake observed in treatment R-2 at the end of the experimental period (Table 2) might have been associated to the smaller development of the digestive tract as a result of decreased final body weight (49-day-old).

The feed conversion of restricted groups was poorer immediately after the restriction periods. Besides, there was a residual effect on feed conversion at the end of the trial (49-day-old), so that poorer feed efficiency was observed in R-2 and R-3. This was expected, since weight gain was lower and there were no differences in feed intake compared to control birds. Boza et al. (1999) have suggested that poorer efficiency might result from the absence of compensatory growth, similar to what was observed in the present study.

The greater intracellular fatty infiltration in the liver at the end of each restriction period (Fig. 1, 2, 3, 4, and Table 3) might suggest that mechanisms of "de novo" synthesis of endogenous fat had been triggered in the liver. Tanaka et al. (1983b) reported that higher levels of dietary carbohydrates induced more lipid synthesis in the liver, which might explain the results of greater fatty infiltration. In the present study, control chicks were fed a 10.1 to $8.3 \%$ of ether extract (100\% DM) diet, and the restriction diet contained only $4.8 \%$ of ether extract (Table 1). Therefore, since there were no differences in feed intake, fat intake in restricted groups was $52 \%$ lower than in the control group. Moreover, crude protein levels in the control diets $(100 \%$ DM) varied from 24.9 to $23.9 \%$, whereas CP level was $26.8 \%$ in the restriction diet. As feed intake was similar between the groups, mean protein intake was 7.6 to $11.2 \%$ higher during the restriction periods. On the other hand, there were minor differences between treatments $(7 \%$ in average) in the levels of easily digestible carbohydrates (non-nitrogenous extract, NNE) 
compared to the differences in protein between control and restricted birds. Therefore, considering the chemical composition of the diets and what has been reported by Tanaka et al. $(1983 a, b)$, it might be assumed that both the lower fat intake and the higher CP and NNE in the restricted diets increased fat synthesis in the liver, and might have affected hepatic fatty infiltration at the end of each restriction period. Nevertheless, it was observed that earlier restriction induced less fatty infiltration on the $49^{\text {th }}$ day of age, which was confirmed by the proximate analysis of the liver. On the contrary, it is possible that the differences between restricted and control groups on the $49^{\text {th }}$ day of age were simply a result of the higher level of fat deposition in the control treatments.

Since there were no statistical differences in TGL levels between treatments at the evaluated ages (Table 5), the changes in hepatic lipid synthesis are not evident. On the $49^{\text {th }}$ day of age, TGL concentration was slightly lower in plasma collected from previously restricted birds. As expected, values in fasted birds were lower and standard deviation was smaller than in non-fasted birds. These results are in accordance to Griffin et al. (1982), who reported that diet effects should be avoided in studies where TGL levels are to be determined. On the $49^{\text {th }}$ day of age, triglyceride levels in the plasma of non-fasted control birds $(66.8 \pm 32.4 \mathrm{ml} / \mathrm{dl})$ were similar to the level of $65.6 \pm 26 \mathrm{ml} / \mathrm{dl}$ reported by Whitehead and Griffin (1982).

Finally, the histological procedures used herein allow clear differentiation of the degrees of hepatic fatty infiltration as a result of qualitative restriction. The results showed very good correlation with hepatic chemical composition, although there was poor correlation with metabolic events (TGL results).

In conclusion, the qualitative restriction resulted in weight gain reduction between $12.1 \%$ and $16.7 \%$. The reduction in weight gain was not enough to stimulate compensatory growth. Qualitative restriction affected both fatty infiltration and proximate analysis of the liver. A new and straightforward method should be developed in order to enable better understanding of the metabolic events concerning fat biosynthesis associated with dietary management in broilers.

\section{REFERENCES}

BARTOV, I. Nutritional factors affecting quantity and quality of carcass fat in chickens. Fed. Proc., v.38, p.2627-2639, 1979.

BARTOV, I.; PLAVNIK, I. Moderate excess of dietary protein increase breast meat yield of broiler chicks. Poult. Sci., v.77, p.680-688, 1998.

BOZA, J.J.; MOENNOZ, D.; VUICHOUD, J. et al. Food deprivation and refeeding influence growth, nutrient retention and functional recovery of rats. J. Nutr., v.129, p.1340-1346, 1999.

CLARKE, S.D.; ARMSTRONG, M.K.; JUMP, D.B. Dietary polyunsaturated fats uniquely suppress rat liver fatty acid synthase and mRNA content. J. Nutr., v.120, p.225-232, 1990,

CORNEJO, S.; LOPEZ, A.; POKNIAK, J. et al. Effect of energy/protein ratio on performance and carcass composition of male broilers. J. Vet. Med., Ser. A, v.38, p.126-133, 1991.

DALRYMPLE, R.H.; BAKER, P.K.; GINGHE, P.E. A repartitioning agent to improve performance and carcass composition of broiler. Poult. Sci., v.63, p.2376-2382, 1984.

FURLAN, R.L.; MACHADO, J.G.C.F.; GIACHETTO, P.F. et al. Desempenho e composição da carcaça de frangos de corte submetidos a diferentes períodos de arraçoamento. Rev. Bras. Zootec., v.31, p.22652273, 2002.

GONZÁlEZ, N.; POKNIAK, J. Composición de alimentos para uso en avicultura. Santiago: Universidad de Chile, 1990. 4p.

GONZALES, E.; JUNQUEIRA, O.M.; MACARI, M. et al. Uso da restrição alimentar quantitativa para diminuir a mortalidade de frangos de corte machos. Rev. Bras. Zootec., v.27, p.129-136, 1998.

GRIFFIN, H.D.; WHITEHEAD, C.C. Plasma lipoprotein concentration as an indicator of fatness in broilers: development and use of a simple assay for plasma very low density lipoproteins. Br. Poult. Sci., v.23, p.307-313, 1982.

GRIFFIN, H.D.; WHITEHEAD, C.C.; BROADBENT, L.A. The relationship between plasma triglyceride concentrations and body fat 
content in male and female broilers - a basis for selection? Br. Poult. Sci., v.23, p.15-23, 1982.

GRIFFIN, H.D.; GUO, K.; WINDSOR, D. et al. Adipose tissue lipogenesis and fat deposition in leaner broiler chicken. J. Nutr., v.122, p.363-368, 1992.

LEESON, S.; ZUBAIR, A.K. Nutrition of the broiler chicken around the period of compensatory growth. Poult. Sci., v.76, p.992999, 1997.

LEESON, S.; SUMMERS, J.D.; CASTON, L.J. Response of broilers to feed restriction or diet dilution in the finisher period. Poult. Sci., v.71, p.2056-2064, 1992.

LOPEZ, M.L.; LEYTON, C.Y.; GRAFF, M.E. Técnicas de histologia y citologia. 2.ed. Santiago: Universidad de Chile, 1982. 52p.

METHODS of analysis. 13.ed. Washington, DC: Association of Official Analytical Chemistry, 1995.

NIR, I.; SHAPIRA, N.; NITSAN, Z. et al. Force feeding effects on growth, carcass and blood composition in the young chick. Br. J. Nutr., v.32, p.229-239, 1984.

PELICANO, E.R.L.; BERNAL, F.E.M.; FURLAN, R.L. et al. Efeito da temperature ambiente e da restrição alimentar protéica ou energética sobre o ganho de peso e crescimento ósseo de frangos de corte. Arq. Bras. Med. Vet. Zootec., v.57, p.353-360, 2005

PLAVNIK, I.; HURWITZ, S. Response of broiler chickens and turkey poults to food restriction of varied severity during early life. $B r$. Poult. Sci., v.32, p.343-352, 1991.

POKNIAK, J.; CORNEJO, S. Effects of energy and protein undernutrition on productive performance and carcass, liver and digestive tract composition of broiler males. Nutr. Rep. Int., v.26, p.319-327, 1982.

SAADOUN, A.; LECLERQ, B. In vivo lipogenesis of genetically lean and fat chickens: effects of nutritional state and dietary fat. $J$. Nutr., v.117, p.428-435, 1987.

SEGOVIA, P.; VILlOUTA, G.; CORNEJO, S. et al. Determinación de triglicéridos en fracciones lipoproteicas de pollos broiler, por métodos químico colorimétrico y de turbidez. $A v$. Cienc. Vet., v.5, p.34-37, 1990.

SOKAL, R.R.; ROHLF, F.J. Biometry. 2.ed. New York: WH Freeman, 1981.

TANAKA, K.; OHTANI, S.; SHIGENO, K. Effect of increasing dietary energy on hepatic lipogenesis in growing chicks. 2. Increase energy by fat or protein supplementation. Poult. Sci., v.62, p.452-458, 1983a.

TANAKA, K.; OHTANI, S.; SHIGENO, K. Effect of increasing dietary energy on hepatic lipogenesis in growing chicks. 1. Increasing energy by carbohydrate supplementation. Poult. Sci., v.62, p.445-451, 1983 b.

TZENG, REN-YU.; BECKER, A.W. Growth patterns of body and abdominal fat weights in male broiler chickens. Poult. Sci., v.60, p.11011106, 1981.

WHITEHEAD, C.C.; GRIFFIN, H.D. Plasma lipoprotein concentration as an indicator of fatness in broilers: effect of age and diet. $B r$. Poult. Sci., v.23, p.299-305, 1982.

ZUBAIR, A.K.; LEESON, S. Changes in body composition and adipocyte cellularity of male broilers subjected to varying degrees of early-life feed restriction Poult. Sci., v.75, p.719-728, 1996. 